\title{
A Modest Appeal for Decent Respect
}

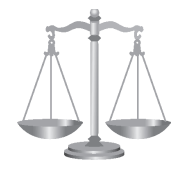

\section{JESSICA} OLIVE

University of Maryland School of Law

\section{DAVID GRAY}

\section{Assistant}

Professor of Law, University of Maryland School of Law
On May I7, 20I0, a five-justice majority of the Supreme Court held in Graham v. Florida ${ }^{\mathrm{I}}$ that the Eighth Amendment bars imposition of life in prison without the possibility of release (LIPWPR) for nonhomicide crimes if the perpetrator was under the age of 18 at the time of his offense. In an opinion penned by Justice Kennedy, the Court held that this prohibition is categorical and reflects the simple fact that LIPWPR is objectively disproportionate ${ }^{2}$ when applied to juveniles whose offenses do not result in death.

Graham rests squarely on foundations Justice Kennedy laid in Roper v. Simmons, 543 U.S. 55I (2005). In Roper, the Court found that juveniles in general are incapable of forming the mental connections to their crimes necessary to justify imposing the most severe punishment their crimes might otherwise warrant. Roper therefore held that, although the death penalty is constitutionally available for homicide, when juveniles kill, the Eighth Amendment entitles them to a discount to at most LIPWPR.

Relying on the same finding of generally reduced culpability, the Court in Graham held that when juveniles commit nonhomicide crimes that warrant permanent incarceration, the Eighth Amendment entitles them to a discount from LIPWPR to at most life in prison with the meaningful possibility of release. As he did in Roper, in Graham Justice Kennedy cited international and comparative law sources to confirm the Court's "independent judgment."3

Justice Thomas, writing for Justice Scalia, Justice Alito, and himself, dissented both from the holding and from the Court's reliance on contemporary sources of international and comparative law. In his dissent, Justice Thomas expressed a quite understandable preference for democratic resolution of disputed issues of public policy, morality, and ethics. Strumming notes familiar from counter majoritarian debates in the academy and contests over judicial activism in Congress and civil society, Justice Thomas lamented the majority's substitution of judgments on proportionate punishment held by appointed justices for those reached among the elected branches.

Although critics may argue that Justice Thomas and his fellow dissenters do not have clean hands on these matters, ${ }^{4}$ Justice Thomas's basic point is well-taken. As a matter of interbranch authority, political legitimacy, and institutional competence, judges are surely not in the best position to design, articulate, and implement sentencing policy. Moreover, interests in the Court's own legitimacy and systemic stability urge justices to bind their constitutional decisions to some fixed point rather than allowing the five justices who find themselves in the majority on any particular issue on any particular day to indulge their idiosyncratic views.

Although we do not endorse the categorical rule announced by the Court in Graham, we nevertheless find most of the dissent's objections to be misplaced. In our view, originalists such as Justice Thomas and Justice Scalia should recognize that the Eighth Amendment imposes objective moral restraints on criminal punishment, that by constitutional design the Court is entrusted with the authority and responsibility to identify and enforce those restraints, and that the epistemic challenge left to the Court in Eighth Amendment cases urges a "decent respect [for] the opinions of mankind" 5 as part of a broader effort to reach the best understanding possible of what punishments are actually cruel and unusual.

Justice Thomas and Justice Scalia have long held the view that members of the Court can best meet demands for stability and legitimacy by binding their opinions to the original public meaning of the text. ${ }^{6}$ In Eighth Amendment cases, this approach usually means searching the record for punishments in common use in 1792. In Graham, Justice Thomas cited evidence that in 1792 the death penalty was available in a majority of states for nonviolent crimes we might now consider rather petty, even if perpetrated by those we now regard as juveniles. Based on that evidence, he concludes that there is no Eighth Amendment bar on LIPWPR for juveniles because few if any of those who lived in the United States in 1792 would have regarded LIPWPR as cruel or unusual regardless of whether the offender happens to be I7, and particularly for violent nonhomicide crimes.?

The problem with this conclusion is that it does not necessarily follow from originalist premises. The Constitution is an inherently aspirational document, designed to "form a more perfect Union," to "establish Justice," to ensure "Tranquility," to "promote the general Welfare,"

Federal Sentencing Reporter, Vol. 23, No. I, pp. 72-74, ISSN I053-9867 electronic ISSN I533-8363. (C) 2010 Vera Institute of Justice. All rights reserved. Please direct requests for permission to photocopy or reproduce article content through the University of California Press's Rights and Permissions website, http://www.ucpressjournals.com/reprintInfo.asp. DOI: I0.I525/fsr.2010.23.I.72. 
and to "secure the blessings of Liberty." ${ }^{8}$ Late-eighteenthcentury Americans were moral realists and believers in the natural law for whom these aspirations were attached to fixed goals in the form of objective moral truths. ${ }^{9}$

Although much of the Constitution is devoted to architectural or utilitarian tasks, at several crucial points the Framers referenced objective moral constraints. Among these constraints is the Eighth Amendment's prohibition on cruel and unusual punishment. Read for its original public meaning, that phrase excludes from public policy punishments that are cruel and unusual. Those who lived in the United States in I792 surely had views on such matters. However, if the originalists' commitment to read the text for its original public meaning is taken seriously, then it would be a mistake to promote their views to the status of objective truth. ${ }^{10}$ At best, investigating their views might show what the drafters of the text intended to prohibit. However, for originalists, original meaning, not original intent, is the proper object of judicial inquiry. ${ }^{\text {II }}$

Regardless of their personal views on moral matters, be they Platonists or Rortian ironists, judges who read the Constitution for its original public meaning are committed to the view that the Eighth Amendment, read for its original public meaning, requires them to declare unconstitutional punishments that are cruel and unusual. That is no easy task, but it is the Court's burden to bear. Within the broad field of contested issues of morality, ethics, and policy, the vast majority of questions are left to the political branches. However, in a very few instances, the Constitution removes these deep questions from the compass of the legislature and rests them with the judiciary. Regardless of how strong public support might be, legislators and executives may not sanction cruel and unusual punishment. If and when they do, it is the Court's institutional responsibility and constitutional duty to declare the offending laws or policies unconstitutional. Declining to do so out of democratic humility, although respectable in the abstract, is an abdication that compromises constitutional design.

This state of affairs leaves originalists such as Justice Thomas and Justice Scalia with an epistemic problem in Eighth Amendment cases such as Graham. How are they to know whether a punishment is cruel and unusual? Senate confirmation does not bring with it the chalice of enlightenment, so modesty surely is called for. Justice Thomas is therefore quite right to express concerns with Justice Kennedy's conclusion that the Court must determine in the exercise of its own "independent judgment" whether the punishment in question violates the Constitution. ${ }^{\mathrm{I2}}$ After all, that assertion seems to bind the Eighth Amendment not to timeless moral truths, but to the idiosyncratic views of five justices. But is there an epistemic method the Court can apply that would provide some assurance that the justices are doing more than giving constitutional dimension to their personal views? We think there is, and believe that this method endorses the Court's references to international and comparative law in Eighth Amendment cases.
The primary epistemic method endorsed by the Court in Eighth Amendment cases is contained in Chief Justice Warren's oft-repeated phrase, “The [Eighth] Amendment must draw its meaning from the evolving standards of decency that mark the progress of a maturing society." ${ }^{13}$ However, as Justice Scalia has pointed out, evolution may sometimes mark decay rather than maturation. ${ }^{14}$ How, then, is the Court to know that an emerging consensus constitutes progress? The project of discourse ethics, advanced most famously in the work of German philosopher Jürgen Habermas, ${ }^{15}$ suggests a promising criterion. The fundamental insight of discourse ethics is that the best answers to normative questions result from conversations among all interested parties who engage one another under ideal conditions. These ideal conditions are characterized by the participants' willingness to offer and consider reasons in the absence of threats of force and to discard, adjust, and adopt views based on the best reasons, all in the hope of reaching consensus.

Measured by this standard, there are very good reasons to be skeptical of views on cruelty in the public record from 1792 America. After all, a substantial majority of those who had legitimate interests in questions of cruelty were excluded from the conversation. U.S. society has since made considerable progress on this score by including more and more people in the conversation, by removing barriers on participation, and by slowly giving equal consideration to new participants' interests and reasons. From a discourse point of view, then, there is good reason to believe that a contemporary consensus on what constitutes cruel and unusual punishment does indeed mark a positive evolution that comes closer to truth than views held by a profoundly racist and patriarchal society.

A discourse method also endorses consulting some international and comparative law sources. After all, we in the United States are not alone in our efforts to avoid cruelty. Quite to the contrary, that commitment is foundational for many nations and is central to the international human rights culture. To the extent that consensus views held by foreign nations or the international community reflect full, fair, and inclusive discursive processes, there seems little reason for the Court not to consider them. ${ }^{\mathrm{I}}$

As Justice Kennedy points out, the results of international and transnational conversations provide considerable evidence of a consensus view that LIPWPR for juveniles cannot be justified. Only eleven nations authorize life without parole for juvenile offenders; only two of them, the United States and Israel, actually use the punishment. Article 37 of the United Nations Convention on the Rights of the Child, which has been ratified by every country on Earth except for the United States and Somalia, states that "capital punishment" and "life imprisonment without the possibility of release" are prohibited for juveniles under I8 years of age. ${ }^{17}$ Although this international consensus is not entirely free from procedural defects, the record is pretty good, and certainly “demonstrates that the Court's rationale has respected reasoning to support it." 18 
Of course, this analysis is far too quick to be fully persuasive. We hope, however, that in this short essay we have been able to provide a bit more depth and credibility both for the Court's decision in Graham to embrace the epistemic challenge posed in Eighth Amendment cases and for its method. In our view, that method rightly includes modest appeals to and a decent respect for those international and comparative law sources that report the results of a more inclusive conversation among those with legitimate interests in fundamental questions of cruelty.

\section{Notes}

$1 \quad 130$ S. Ct. 2011 (2010). Graham was charged with armed burglary and attempted armed robbery for acts perpetrated when he was 16. Expressing considerable regret and the intention to change his life, Graham pleaded guilty in exchange for three years' probation. During his probationary period, Graham participated in a series of armed home inva. sion robberies. A judge new to Graham's case found Graham guilty of violating the terms of his parole. The prosecutor requested a sentence of thirty to forty-five years' imprisonment. Graham's attorney requested five years. A presentence report issued by the Florida Department of Corrections recommended four years. Finding that Graham had elected a life of crime that rendered him unsuitable for release, the judge sentenced Graham to life, which, in the Florida system, is a determinate sentence without the possibility of early release absent executive clemency.

2 Objectively disproportionate means that LIPWPR is too severe when imposed on juveniles for nonhomicide crimes regardless of what punishments are imposed for more serious crimes. We use the phrase here in contrast with comparative proportionality, which would be concerned with how severe the punishments inflicted for nonhomicide crimes are compared with punishments inflicted for homi. cide crimes.

$3130 \mathrm{~S}$. Ct. at 2033-34.

4 Most recently, critics have pointed to the Court's decision in Citizens United v. Federal Election Commission, 558 U.S. 50 (2010), as an example of conservative activism that violates principles of judicial restraint.

5 The Declaration of IndePEndence $\mathbb{1} 1$ (U.S. 1776), reprinted in 1 U.S.C. at xliii (2000). Although some argue that this phrase from the Declaration of Independence makes international and comparative law sources relevant to most if not all cases decided by domestic courts, we do not.
6 Although Justice Alito's public record is not as well estab. lished, his vote in Graham at least indicates sympathy for this version of originalism.

7 In support of this point, Justice Thomas referred to Chief Justice Roberts's concurring opinion, which recounted the case of a 17-year-old who "beat and raped an 8-year-old girl before leaving her to die under 197 pounds of rock in a recy. cling bin in a remote landfill," and the case of two juveniles who "gang raped a woman and forced her to perform oral sex on her 12-year-old son." 130 S. Ct. at 2041 (Roberts, C.J., concurring).

8 U.S. CONST. pmbl.

9 See Antonin Scalia, Reply, in A Matter of Interpretation: Fed. ERAL CourTS AND THE LAW 146 (Amy Gutmann ed., 1997); David C. Gray, Why Justice Scalia Should Be a Constitutional Comparativist...Sometimes, 59 StAN. L. Rev. 1249, 1262 (2007).

10 This assertion assumes that those who read and wrote the Eighth Amendment in 1792 did not hold a theory of seman. tics by which historical or contemporary use of abstract moral terms fixes their meanings. Although various forms of this view were in circulation in 1792 and are quite common today, our countrymen of 1792 appear to have been more inclined to the view that deific law or the law of nature pro. vided a stable referent for such words as justice and cruel.

11 Gray, supra note 9, at 1265. See also Scalia, supra note 9, at 3 (explaining that he consults the Framers' views when interpreting the Constitution "not because ... their intent is authoritative ... but rather because their writings . . display how the text of the Constitution was originally understood.").

12 Graham, supra note 1 at 10 (Thomas, J., dissenting).

13 Trop v. Dulles, 356 U.S. 86, 101 (1958).

14 Scalia, supra note 8, at 40-41 ("A society that adopts a bill of rights is skeptical that 'evolving standards of decency' always 'mark progress,' and that societies always 'mature,' as opposed to rot.").

15 See, e.g., Jürgen Habermas, Moral Consciousness and CommuniCATIVE ACTION 43-115 (1990).

16 Cf. United States v. Then, 56 F.3d 464, 469 (2d Cir. 1995) (Calabresi, J., concurring) ("Wise parents ... do not hesitate to learn from their children.").

17 United Nations Convention on the Rights of the Child, art. 37(a), U.N. Doc. A/44/736, 28 I.L.M. 1456 (Nov. 20, 1989). Cf. Rome Statute, art. 26, U.N. Doc. A/CONF. 183/9 (Jan. 16, 2002) ("The Court shall have no jurisdiction over any person who was under the age of 18 at the time of the alleged com. mission of a crime."). But see MARK DrumbL, Not So Simple: Child Soldiers, Justice, and the International Legal Imagination (forthcoming 2011) (arguing against categorical conceptions of juvenile culpability for war crimes).

18130 S. Ct. at 2034. 